\title{
Recurrence in Uterine Tumors with Ovarian Sex-Cord Tumor Resemblance: A Case Report and Systematic Review
}

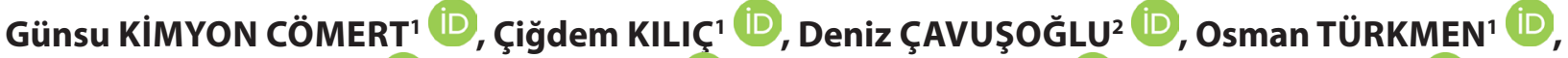 \\ Alper KARALOK ${ }^{1}$ iD, Taner TURAN ${ }^{1}$ iD, Derman BAŞARAN ${ }^{1}$ iD, Nurettin BORAN ${ }^{1}$ iD \\ Department of 'Gynecologic Oncology, 2Pathology, Etlik Zubeyde Hanim Women's Health Training and Research Hospital, \\ Faculty of Medicine, University of Health Sciences, ANKARA, TURKEY
}

\begin{abstract}
Objective: The aim of this study was to evaluate the prognostic factors of recurrence in uterine tumors resembling ovarian sex-cord tumors (UTROSCT) and to determine clinical-pathological characteristics, treatment options and outcome.
\end{abstract}

Material and Method: An electronic literature search was conducted from 1976 to 2018. After the comprehensive evaluation and conjunction with our case, the study included 79 cases.

Results: The median age at initial diagnosis was 49 years (range; 16-86 years). The age was under 40 years in 21 (26.6\%) patients. Whereas 68 patients underwent at least hysterectomy, 9 patients had organ sparing surgery. There was necrosis in 4 (5.1\%) patients, atypia in 16 (20.3\%) patients, and infiltrative tumor border in 34 (43\%) patients. At least one mitosis per 10 high power fields was determined in 36 (45.5\%) patients. The tumor involved at least part of the myometrium in 54 (68.3\%) patients. Median follow-up time was 30 months (range; 3-296 months). Recurrence was determined in $5(6.3 \%)$ patients. The disease free survival (DFS) was significantly related only to surgery type. None of the pathologic features were associated with DFS. The 5 -year DFS was $86 \%$ and $96 \%$ in patients who underwent organ sparing surgery or not, respectively $(\mathrm{p}=0.038)$.

Conclusion: The accurate pathologic diagnosis of UTROSCT has great value in shaping surgical management and management during the follow-up period. Organ sparing surgery was related to poor DFS. Although recurrence is rare, it should be kept in mind for patients with UTROSCT.

Key Words: Uterine neoplasms, Recurrence, UTROSCT, Surgery, Prognosis

\section{INTRODUCTION}

Uterine tumors with sex-cord-like elements can be divided into two groups. The first group of tumors is called endometrial stromal tumors with sex cord-like elements (ESTSCLEs) involving endometrial stromal neoplasms with focal areas $(<50 \%)$ resembling ovarian sex-cord elements. The second group of tumors is called uterine tumors resembling ovarian sex-cord tumors (UTROSCTs) corresponding to uterine tumors with a predominant or exclusive pattern similar to ovarian sex-cord tumors (1, 2). This morphologic differentiation is clinically significant because these tumors have different biological behaviors. ESTSCLE has a tendency for recurrence and metastases, whereas UTROSCT usually shows more benign clinical behavior (3). UTROSCTs rarely recur and are thus considered uterine tumors with low malignant potential (4). UTROSCTs are extremely rare tumors mostly documented as case series in the literature; therefore, it is difficult to draw

(Turk Patoloji Derg 2018, 34:225-233)

Received : 03.12.2017 Accepted : 03.04.2018 a distinct conclusion about the management or recurrence rates of these tumors.

In this study, a recurrent case of UTROSCT is presented. This analysis evaluated prognostic factors related to UTROSCT recurrence and determined clinicalpathological characteristics, treatment options, and outcomes of UTROSCT.

\section{CASE REPORT}

A 61-year-old patient was referred to our gynecologiconcology clinic because of a UTROSCT diagnosis. She underwent total abdominal hysterectomy (TAH) and bilateral salpingo-oophorectomy (BSO) with a diagnosed pelvic mass at another center. The largest diameter of her tumor was $70 \mathrm{~mm}$.

In the differential diagnosis of UTROSCT, we considered ESTSCLE, low-grade endometrial stromal sarcoma, epithelioid leiomyoma, and endometrioid carcinoma

Correspondence: Günsu KİMYON CÖMERT

Etlik Zubeyde Hanim Women's Health Training and Research Hospital,

Faculty of Medicine, University of Health Sciences,

Department of Gynecologic Oncology, ANKARA, TURKEY

E-mail: gunsukimyon@gmail.com Phone: +90 3123220180 
with sex-cord-like elements. Microscopic evaluation of the specimen was reviewed by pathologists with expertise in gynecologic oncology. The pathologic result showed an endometrial-located tumor. There was a suspicion of superficial focal myometrial invasion. Microscopic evaluation showed anastomosing cords, trabeculae, nests, and tubules of epithelial-like cells found in a fibroblastic stroma (Figure 1). The stromal cells had mild pleomorphism and no necrosis. The mitotic index was 2 per 10 high power fields (HPF). The neoplasm had an infiltrative growth pattern, but there was no vascular invasion. Immunohistochemical analysis was performed. The neoplasm was positive for calretinin, vimentin (Figure 2) CD56 (Figure 3), estrogen receptors (Figure 4), progesterone receptors, Wilms' tumor Protein 1 (Figure 5), synaptophysin, and chromogranin. However, the neoplasm was negative for CD10, EMA, desmin, CD99, and inhibin.

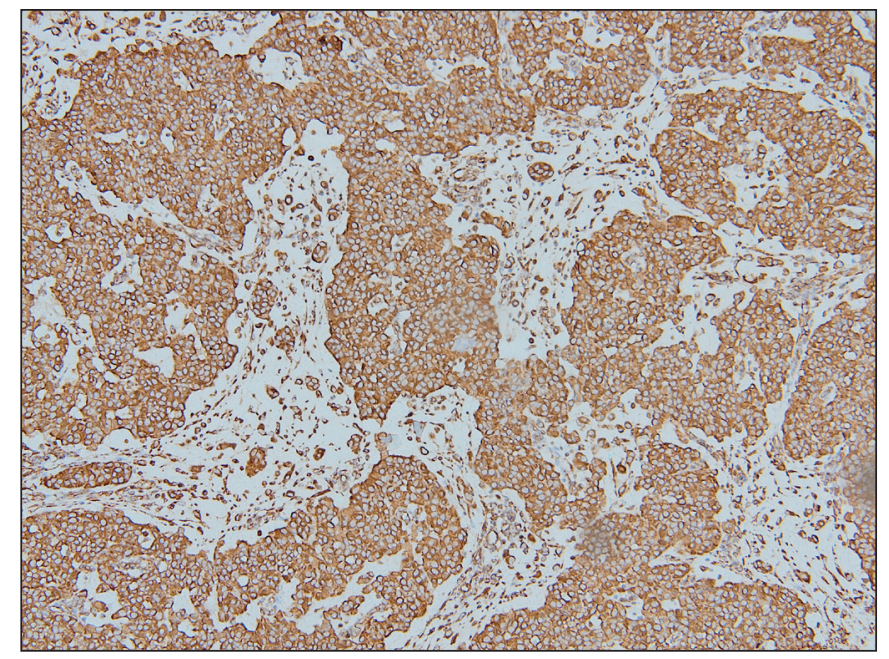

Figure 2: Vimentin positivity (IHC; x100).

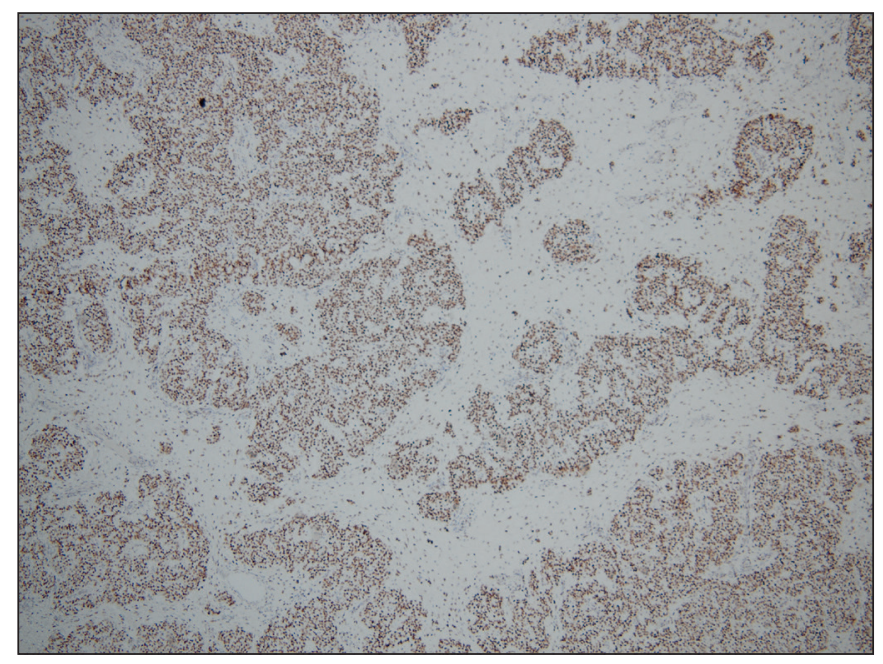

Figure 4: Estrogen receptor positivity (IHC; x100).

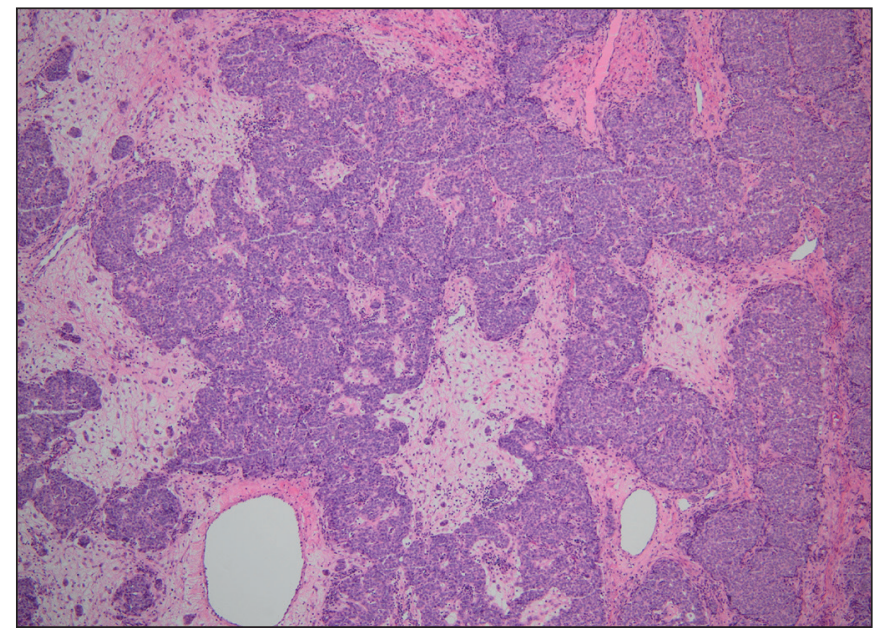

Figure 1: Anastomosing cords, trabeculae, nests and tubules of epithelial-like cells were lying in a fibroblastic stroma. The stromal cells had mild pleomorphism and no necrosis (H\&E; $\mathrm{x} 100)$.

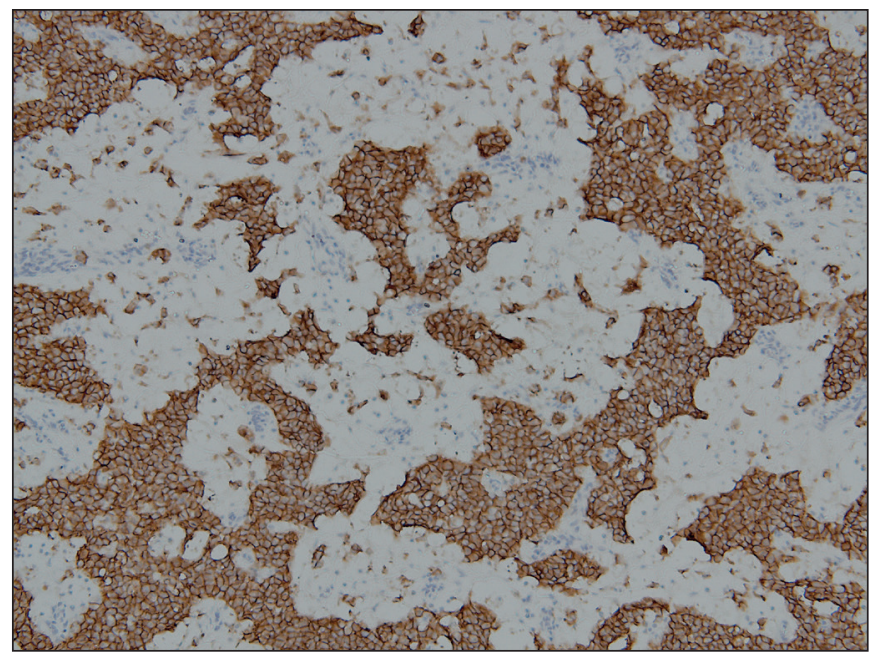

Figure 3: CD56 positivity (IHC; x100).

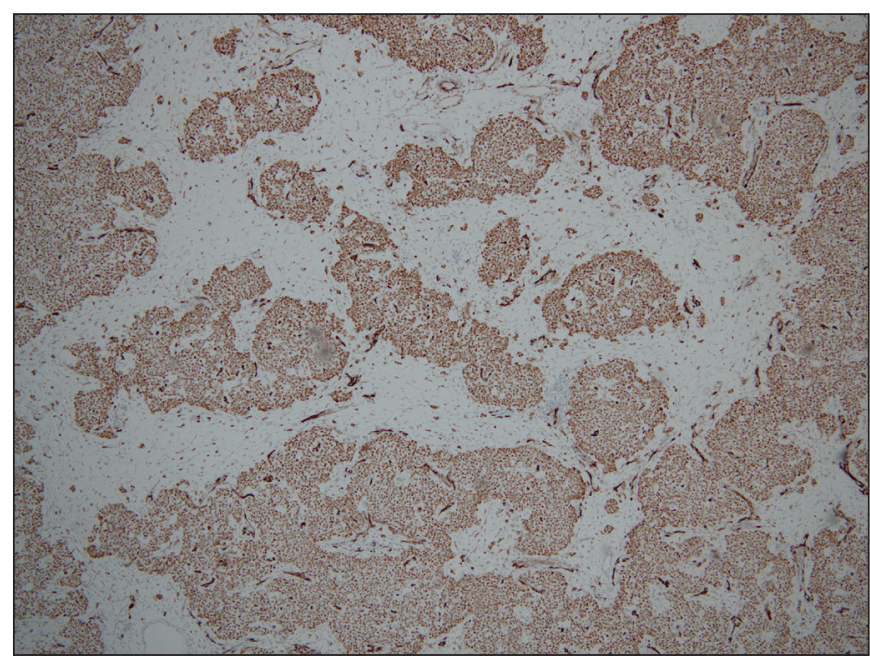

Figure 5: Willms' tumor protein-1 (WT1) positivity (IHC; x100). 
According to these findings, the pathologic diagnosis was reported as UTROSCT. A $50 \mathrm{~mm}$ pelvic mass was determined incidentally via ultrasonography and magnetic resonance imaging during follow-up at 60 months after the initial diagnosis.

Upon diagnosis, the patient underwent cytoreductive surgery with pelvic mass excision, omentectomy and a tumoral implant resection from the spleen; no tumor was visible at the completion of the surgery. The pathology result of the recurrent disease was reported as UTROSCT with pathological features similar to the initial tumor. The patient received adjuvant hormone therapy for one year, first with megestrol acetate (ceased because of the side effects) and then with letrozole. Three months after completing therapy, she underwent cytoreductive surgery because of secondary recurrence in the pelvis and abdomen. There was a pelvic mass behind the bladder and tumoral implants on the anterior surface of the abdominal wall. At the end of the surgery, maximal cytoreduction with no visible tumor was achieved. According to the medical oncologist's suggestion, adjuvant chemotherapy was planned, but the patient refused chemotherapy. She is alive and disease free seven months after secondary surgery. The follow-up time was 83 months from initial diagnosis.

\section{MATERIALS and METHODS}

\section{Literature Review}

A systematic review of the medical literature was performed to identify articles about uterine tumors resembling ovarian sex cord tumors. The electronic literature search was conducted from 1976 to January 2018 using PubMed/ MEDLINE for English language abstracts. The search included the following medical subject headings (MeSH) or keywords: 'uterine tumor resembling ovarian sex cord tumors' and 'UTROSCT'. After the search was completed, 63 articles were found. After the first evaluation, 23 articles were excluded because of the detailed reasons in the research chart (Figure 6). After a comprehensive evaluation of all cases $(\mathrm{N}=120)$ from 40 articles $(2,5-42)$, the study excluded ESTSCLE cases $(n=14)$ and patients who only underwent curettage without detailed clinical data such as therapy type after curettage, follow-up time, and recurrence status ( $\mathrm{n}=$ 3). Additionally, cases that were referred as consultations $(n=32)$ or not clarified $(n=2)$ as which was the institutional were not included in the study to avoid confusion related to probable case duplication (43). The study evaluated a total of 79 cases.

Tumor size was defined as the largest tumor diameter in the uterus. Tumors were categorized into three types: endometrial (polypoid and confined to the endometrium), myometrial (involving at least part of the myometrium but no serosa; this included submucosal tumors on hysteroscopy), and serosal (involving all the uterine layers, including the serosa). The presence of mitosis was accepted as the presence of at least 1 mitosis per $10 \mathrm{HPF}$. Surgery types were categorized as either organ-preserving (including myomectomy, hysteroscopy, uterine mass excision, and transvaginal mass extirpation) or non-organ-

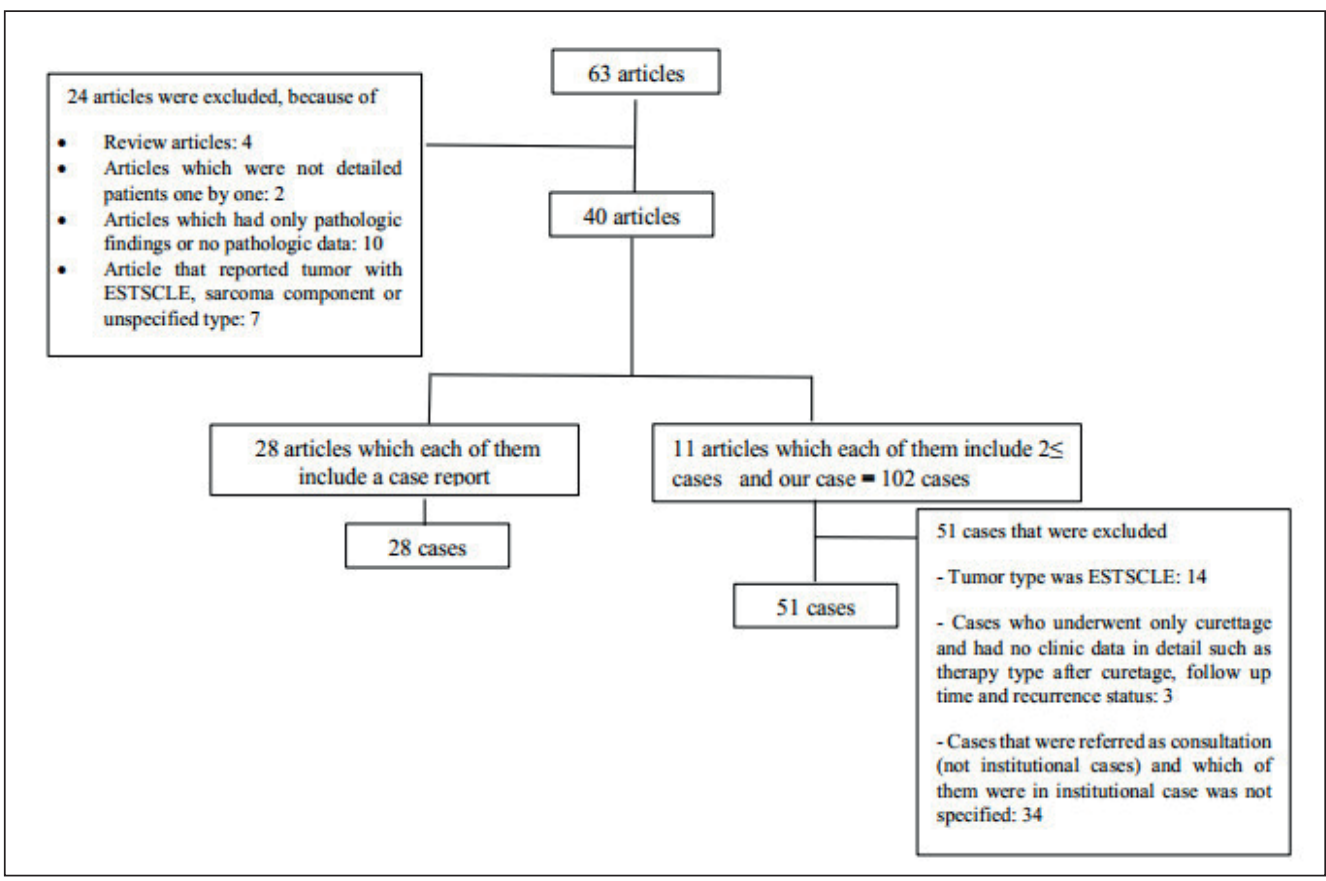

Figure 6: Chart of the literature electronic search of UTROSCT (Abbr. in figure: ESTSCLE; endometrial stromal tumors with sex cord-like elements). 
preserving (all others). Disease-free survival (DFS) was defined as the time period from initial therapy to recurrence or last contact. Time from initial therapy to death or the last contact was defined as median follow-up time.

SPSS 17.0 (SPSS Inc., Chicago, IL) was used for the data management and statistical analysis. Descriptive statistics were expressed as mean \pm standard deviation (SD) or median (min-max) for continuous variables and number/ percentage for categorical variables. The Kaplan-Meier method was used for the assessment of survival outcomes. Survival curves were compared using the log-rank test. $P$-values less than 0.05 were considered significant.

\section{Results of Systematic Review Analysis}

The median age of entire cohort at initial diagnosis was 49 years (range: 16-86 years). Age was under 40 years in 21 (26.6\%) patients and $\leq 30$ years in $11(14 \%)$ patients. Four (5.1\%) patients were in the adolescent and young adult age range ( $\leq 25$ years). The most common symptom was abnormal bleeding (67.1\%). Other reported symptoms were pelvic pain in $4(5.1 \%)$ patients, palpable pelvic masses in 2 (2.5\%) patients and abnormal bleeding with galactorrhoea in $1(1.3 \%)$ patient. Fourteen $(17.7 \%)$ patients were asymptomatic. Symptoms were unreported in five patients.

One patient received primary radiotherapy. One patient underwent neoadjuvant radiotherapy followed by surgery (hysterectomy and lymphadenectomy). The remaining patients (n: 77) underwent surgery. Surgery was performed as a hysterectomy with or without BSO in 61 patients, hysterectomy with BSO and lymphadenectomy in 7 patients, myomectomy in 2 patients, hysteroscopic mass resection in 6 patients, and transvaginal mass extirpation in 1 patient. Three patients received adjuvant therapy. One patient underwent adjuvant radiotherapy (external beam radiotherapy and vaginal vault brachytherapy) following hysterectomy and BSO. One patient who underwent surgery (hysterectomy with BSO and lymphadenectomy) received adjuvant chemotherapy (BEP protocol (four cycles): bleomycin, etoposide, and cisplatin) followed by radiotherapy because of the positive surgical margin in the parametrium. One patient who had an iliac lymph node metastasis in the final pathology received adjuvant progestin therapy following surgery (hysterectomy, BSO, and lymphadenectomy).

The median tumor diameter was $50 \mathrm{~mm}$ (range: 4-140 $\mathrm{mm})$. In 75 (94.9\%) patients, there was a single lesion. There was necrosis in $4(5.1 \%)$ patients and atypia in $16(20.3 \%)$ patients. At least one mitosis per $10 \mathrm{HPF}$ was determined in $36(45.6 \%)$ patients. In three cases, the mitotic index was
8, 9, and 11 per $10 \mathrm{HPF}$. In four cases, the mitotic index reported as $<10$ per $10 \mathrm{HPF}$. In the remaining cases with mitosis, it was $<5$ per $10 \mathrm{HPF}$. The tumor border was infiltrative in $34(43 \%)$ patients. A pushing pattern with a well-circumscribed border was determined in 28 (35.4\%) patients. The tumor was confined to the endometrium in 18 (22.8\%) patients, involving at least part of the myometrium but no serosa in $46(58.2 \%)$ patients, and involving all layers (serosa included) in $8(10.1 \%)$ of patients. There was cervical involvement in $3(3.8 \%)$ patients. The extra-uterine spread was determined in $5(6.3 \%)$ patients. The locations of extra-uterine spread were in the ovary and appendices epiploicae in one patient, ovary and parametrium in one patient, appendices epiploicae alone in one patient, and internal iliac lymph node metastases in two patients. Clinical-pathologic features of the entire cohort are shown in Table I.

Table I: Clinical-pathologic features of entire cohort

\begin{tabular}{|c|c|c|c|}
\hline Parameters & & $\mathbf{n}$ & $(\%)$ \\
\hline \multirow{3}{*}{$\begin{array}{l}\text { Menopausal } \\
\text { status }\end{array}$} & Premenopausal & 32 & 40.5 \\
\hline & Postmenopausal & 29 & 36.7 \\
\hline & $\mathrm{NR}$ & 18 & 22.8 \\
\hline \multirow{3}{*}{$\begin{array}{l}\text { Number of } \\
\text { lesion }\end{array}$} & Single & 75 & 84.9 \\
\hline & Multiple $(2 \leq)$ & 3 & 3.8 \\
\hline & NR & 1 & 1.3 \\
\hline \multirow{4}{*}{$\begin{array}{l}\text { Involved } \\
\text { layers of } \\
\text { uterus }\end{array}$} & Confined to endometrium & 18 & 22.8 \\
\hline & $\begin{array}{l}\text { At least part of the } \\
\text { myometrium but no serosa }\end{array}$ & 46 & 58.2 \\
\hline & All layers (serosa incl.) & 8 & 10.1 \\
\hline & NR & 7 & 8.9 \\
\hline \multirow{3}{*}{$\begin{array}{l}\text { Border type } \\
\text { of tumor }\end{array}$} & Pushing or well circumscribed & 28 & 35.4 \\
\hline & Infiltrative & 34 & 43.0 \\
\hline & NR & 17 & 21.5 \\
\hline \multirow{3}{*}{$\begin{array}{l}\text { Presence of } \\
\text { atypia }\end{array}$} & Absent & 18 & 22.8 \\
\hline & Present & 16 & 20.3 \\
\hline & NR & 45 & 57.0 \\
\hline \multirow{3}{*}{$\begin{array}{l}\text { Presence of } \\
\text { mitosis }\end{array}$} & Absent & 18 & 22.8 \\
\hline & Present & 36 & 45.6 \\
\hline & NR & 25 & 31.6 \\
\hline \multirow{3}{*}{$\begin{array}{l}\text { Presence of } \\
\text { necrosis }\end{array}$} & Absent & 20 & 25.3 \\
\hline & Present & 4 & 5.1 \\
\hline & NR & 55 & 69.6 \\
\hline \multirow{2}{*}{$\begin{array}{l}\text { Cervical } \\
\text { involvement }\end{array}$} & Absent & 76 & 96.2 \\
\hline & Present & 3 & 3.8 \\
\hline \multirow{3}{*}{$\begin{array}{l}\text { Presence of } \\
\text { extra-uterine } \\
\text { spread }\end{array}$} & Absent & 54 & 68.4 \\
\hline & Present & 5 & 6.3 \\
\hline & NR & 20 & 25.3 \\
\hline
\end{tabular}

NR: Not reported. 


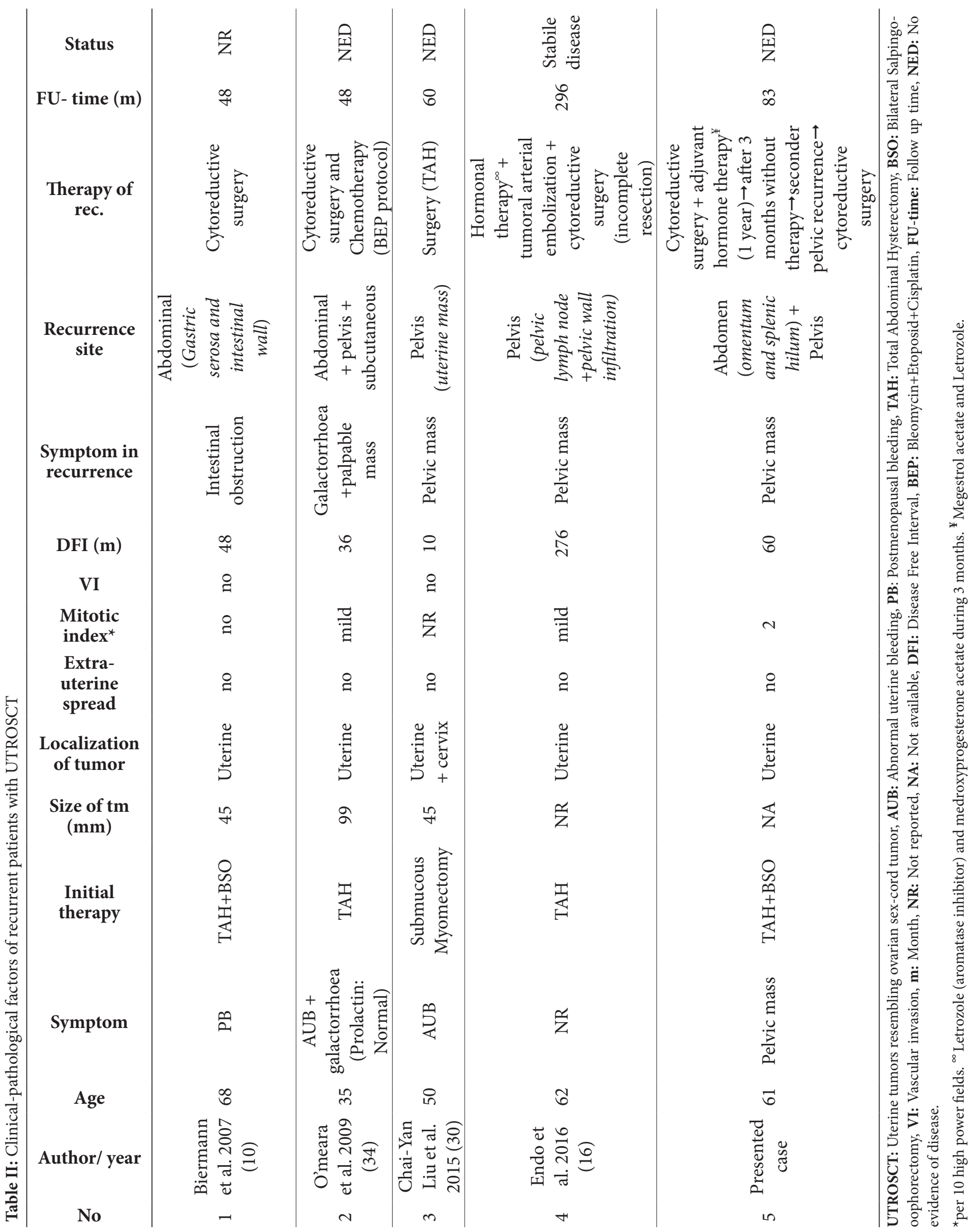




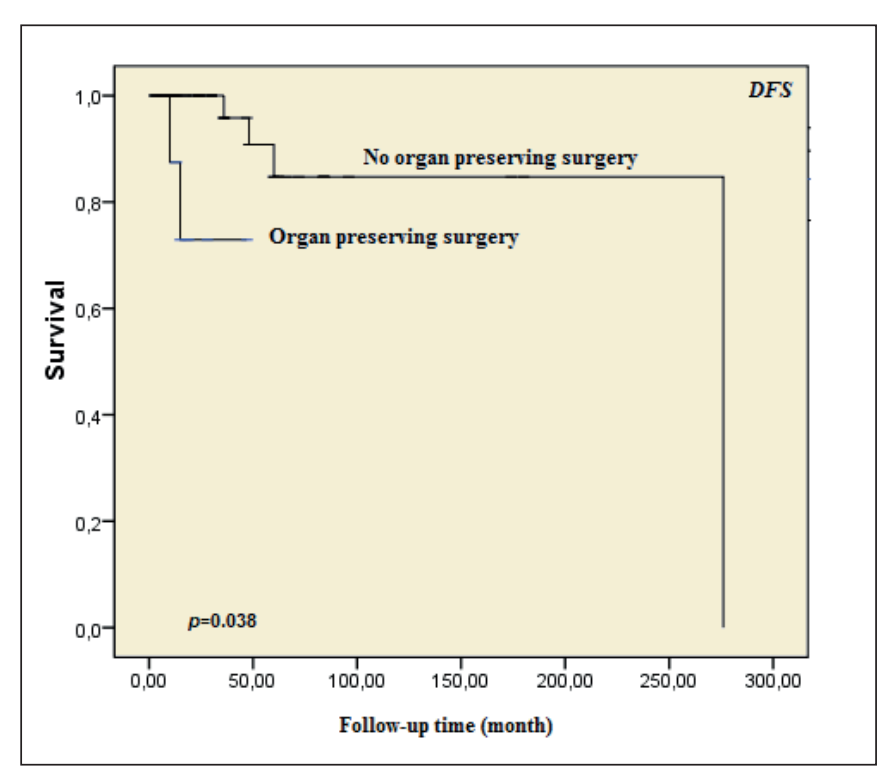

Figure 7: The 5-year disease free survival was $86 \%$ and $96 \%$ in patients with UTROSCT who underwent organ preserving surgery or not, respectively $(\mathrm{p}=0.038)$.
Median follow-up time was 30 months (range: 3-296 months). Recurrence was determined in 5 (6.3\%) patients. Median recurrence time was 48 months (range: 10-276 months). The most common recurrent site was in the pelvic region. Recurrences were in pelvis alone for two patients, in the abdomen alone for one patient, in the abdomen and pelvis for one patient, and in abdomen + pelvis + subcutaneous region for one patient. All but one patient with recurrence underwent cytoreductive surgery. One patient (Case 4) received hormonal therapy for three months (letrozole and medroxyprogesterone acetate) and underwent embolization of the tumor arteries followed by surgery. Adjuvant therapy was given as chemotherapy (BEP) to 1 patient (Case 2) and as hormonal therapy (megestrol acetate and letrozole) to one patient (Case 5). Characteristics and pathological findings of patients with recurrent disease are detailed in Table II.

The five-year DFS was $83.4 \%$. The DFS was significantly related only to surgery type. The five-year DFS was

Table III: Association between clinic-surgical-pathologic factors and disease-free survival (DFS)

\begin{tabular}{|c|c|c|c|}
\hline Parameters & & 5-year DFS (\%) & $p$ value \\
\hline \multirow{2}{*}{ Age } & $<49$ & 90 & \multirow{2}{*}{0.651} \\
\hline & $49 \leq$ & 81 & \\
\hline \multirow{2}{*}{ Menopausal status } & Premenopausal & 86 & \multirow{2}{*}{0.810} \\
\hline & Postmenopausal & 76 & \\
\hline \multirow{2}{*}{ Tumor diameter $(\mathrm{mm})$} & $<50$ & 82 & \multirow{2}{*}{0.441} \\
\hline & $50 \leq$ & 93 & \\
\hline \multirow{2}{*}{ Number of lesions } & Single & 98 & \multirow{2}{*}{0.841} \\
\hline & Multiple $(2 \leq)$ & 100 & \\
\hline \multirow{3}{*}{ Involved layers of uterus } & Confined to endometrium & 83 & \multirow{3}{*}{0.792} \\
\hline & At least part of the myometrium but no serosa & 96 & \\
\hline & All layers (serosa incl.) & 100 & \\
\hline \multirow{2}{*}{ Border type of tumor } & Pushing or well circumscribed & 89 & \multirow{2}{*}{0.269} \\
\hline & İnfiltrative & 100 & \\
\hline \multirow{2}{*}{ Presence of atypia } & Absent & 100 & \multirow{2}{*}{0.480} \\
\hline & Present & 83 & \\
\hline \multirow{2}{*}{ Presence of mitosis } & Absent & 80 & \multirow{2}{*}{0.653} \\
\hline & Present & 66 & \\
\hline \multirow{2}{*}{ Presence of necrosis } & Absent & 67 & \multirow{2}{*}{0.414} \\
\hline & Present & 100 & \\
\hline \multirow{2}{*}{ Cervical involvement } & Absent & 98 & \multirow{2}{*}{0.649} \\
\hline & Present & 100 & \\
\hline \multirow{2}{*}{ Presence of extra-uterine spread } & Absent & 98 & \multirow{2}{*}{0.360} \\
\hline & Present & 100 & \\
\hline \multirow{4}{*}{$\begin{array}{l}\text { Categorization of surgery } \\
\text { according to extension }\end{array}$} & Hysterectomy & 87.5 & \multirow{2}{*}{0.969} \\
\hline & Hysterectomy with BSO & 82 & \\
\hline & Hysterectomy $\pm \mathrm{BSO}$ & 84 & \multirow{2}{*}{0.681} \\
\hline & Hysterectomy with BSO + Lymphadenectomy & 100 & \\
\hline \multirow{2}{*}{ Organ preserving surgery ${ }^{¥}$} & Yes & 86 & \multirow{2}{*}{$0.038^{*}$} \\
\hline & No & 96 & \\
\hline
\end{tabular}

BSO: Bilateral salpingo-oophorectomy, ${ }^{¥}$ organ preserving surgery included patient underwent myomectomy, hysteroscopy, uterine mass excision and transvaginal mass extirpation. ${ }^{*} \mathrm{p}<0.05$ is statistically significance. 
$86 \%$ and $96 \%$ for patients who underwent or did not undergo organ-sparing surgery, respectively $(p=0.038)$ (Figure 7). No statistically significant relationship existed between hysterectomy only and hysterectomy with BSO (87.5\% vs. $82 \%$; respectively, $p=0.969)$ groups. Age $(<49$ vs. $49 \leq)$, menopausal status, tumor diameter $(<50 \mathrm{~mm} v s .50 \mathrm{~mm} \leq)$, presence of cervical involvement, presence of extra-uterine spread, border type of the tumor, number of lesions, mitosis, atypia, necrosis and involved layers of the uterus were not associated with DFS (Table III). End status was reported in 56 patients in the literature and no patients died because of the disease.

\section{DISCUSSION}

UTROSCT is one of the rarer types of uterine tumors. The differential diagnosis of UTROSCT should consider epithelioid leiomyoma, ESTSCLE, endometrioid carcinoma with sex cord-like elements, carcinosarcoma, and adenosarcoma (44). Even though pathologic features in H\&E staining for UTROSCT have been detailed, evaluation with immunohistochemical staining is usually needed to achieve a correct diagnosis. Various immunophenotypes are characteristic of UTROSCT (44). Factors affecting the clinical behavior of UTROSCT remain unknown.

The long-term clinical behaviors of UTROSCT are less aggressive than ESTSCLE $(4,18)$. The recurrence rate is approximately $13 \%$ in sex-cord-like uterine tumors, but most include ESTSCLE (45). A popular belief is that UTROSCT has a clinical pattern like a benign neoplasm (23). However, UTROSCT should be considered as a neoplasm with a low malignant potential because of potential recurrence or extra-uterine spread $(4,6,44)$. Although UTROSCT has a low recurrence rate (34), this rate is not clearly specified in the literature. Moore and McCluggage reported eight cases with recurrence and a recurrence rate of $23.5 \%$ for UTROSCT (43). Their report is the largest case series documented in the medical literature; however, they attributed the high percentage rate to the inclusion of referred patients with metastases to their institution for consultation. According to our literature analysis, the average recurrence rate was $6.3 \%$ for UTROSCT.

The preferable treatment for UTROSCT is surgery (4, 30). However, this treatment remains controversial. Blake et al. reported that the addition of adnexectomy to a hysterectomy was not related to differences in DFS compared to hysterectomy alone (4). Similarly, the addition of BSO or lymphadenectomy in the present study was not associated with improvement in survival. A considerable number of patients with UTROSCT (26.6\%) were under 40 years old, including adolescent and young adult patients (5.1\%). Because of the high probability of fertility and organ-preserving desire in this age group, a clinical decision about surgery type in UTROSCT can be difficult. Therefore, it is important to determine risk factors for recurrence or extra-uterine disease in this population of UTROSCT. Pradhan et al. reported that infiltrative border, vascular invasion, frequent mitotic figures, serosal rupture, stromal predominance and cytologic atypia were associated with the recurrence of UTROSCT (44). Infiltrative borders, vascular invasion, and mitotic count have been asserted as possible predictive factors for aggressive UTROSCT (23). Moore and McCluggage determined that necrosis and mitotic activity were significantly associated with the malignant behavior of UTROSCT (43). According to our results, statistically significant differences in DFS were only determined between patients with and without organpreserving surgery. However, no clinical-pathological factors such as age, menopausal status, atypia, necrosis, mitosis, type of border, number or location of the lesion, the diameter of the tumor, or cervical involvement were related to recurrence in our analysis. Although DFS was lower in patients who underwent organ-preserving surgery (5-year DFS 85\% vs. 96\%), no patients died because of the disease. Complete resection with hysterectomy should be a primary option in UTROSCT. In patients who desire fertility, organ-preserving surgery can be considered after giving comprehensive information about recurrence rates and lower DFS. Patients who choose the conservative management must be followed up closely. Complete surgery must be recommended following childbirth. However, the four patients included in our case experienced disease recurrence, although they had hysterectomies. The role of adjuvant therapy is equivocal and reaching a conclusion is not possible on this issue due to the lack of cases in the literature. Due to the absence of distinct prognostic factors, close follow-up is necessary for all patients.

The main limitations of this study are the small study group size and the retrospective design. Nevertheless, we contributed one case with recurrent UTROSCT to the medical literature. According to our knowledge, our study is one of the largest reports of this phenomenon that has comprehensively evaluated the recurrence pattern and assessed the DFS by considering types of treatment.

In conclusion, the accurate pathologic diagnosis of UTROSCT has an important value in shaping surgical management and management during the follow-up period. Patients with UTROSCT require close follow-up to be aware of recurrence. Surgery type is the only factor as- 
sociated with DFS. The main treatment is complete surgery (hysterectomy). However, organ-sparing surgery can be useful for young adult patients and those individuals desiring fertility. Given the poor DFS, patients managed with conservative therapy should be followed up carefully and closely for recurrence.

\section{CONFLICT of INTEREST}

The authors declare no competing interest. This research did not receive any specific grant from funding agencies in the public, commercial, or not for profit sectors.

\section{REFERENCES}

1. Staats PN, Garcia JJ, Dias-Santagata DC, Kuhlmann G, Stubbs H, McCluggage WG, De Nictolis M, Kommoss F, Soslow RA, Iafrate AJ, Oliva E. Uterine tumors resembling ovarian sex cord tumors (UTROSCT) lack the JAZF1-JJAZ1 translocation frequently seen in endometrial stromal tumors. Am J Surg Pathol. 2009;33:120612.

2. Clement PB, Scully RE. Uterine tumors resembling ovarian sexcord tumors. A clinicopathologic analysis of fourteen cases. Am J Clin Pathol. 1976;66:512-25.

3. Czernobilsky B. Uterine tumors resembling ovarian sex cord tumors: an update. Int J Gynecol Pathol. 2008;27:229-35.

4. Blake EA, Sheridan TB, Wang KL, Takiuchi T, Kodama M, Sawada $\mathrm{K}$, Matsuo K. Clinical characteristics and outcomes of uterine tumors resembling ovarian sex-cord tumors (UTROSCT): A systematic review of literature. Eur J Obstet Gynecol Reprod Biol. 2014;181:163-70.

5. Abdullazade S, Kosemehmetoglu K, Adanir I, Kutluay L, Usubutun A. Uterine tumors resembling ovarian sex cordstromal tumors: Synchronous uterine tumors resembling ovarian sex cord-stromal tumors and ovarian sex cord tumor. Ann Diagn Pathol. 2010;14:432-7.

6. Anastasakis E, Magos AL, Mould T, Economides DL. Uterine tumor resembling ovarian sex cord tumors treated by hysteroscopy. Int J Gynaecol Obstet. 2008;101:194-5.

7. Aziz O, Giles J, Knowles S. Uterine tumours resembling ovarian sex cord tumours: A case report. Cases J. 2009;2:55.

8. Bakula-Zalewska E, Danska-Bidzinska A, Kowalewska M, Piascik A, Nasierowska-Guttmejer A, Bidzinski M. Uterine tumors resembling ovarian sex cord tumors, a clinicopathologic study of six cases. Ann Diagn Pathol. 2014;18:329-32.

9. Berretta R, Patrelli TS, Fadda GM, Merisio C, Gramellini D, Nardelli GB. Uterine tumors resembling ovarian sex cord tumors: A case report of conservative management in young women. Int J Gynecol Cancer. 2009;19:808-10.

10. Biermann K, Heukamp LC, Buttner R, Zhou H. Uterine tumor resembling an ovarian sex cord tumor associated with metastasis. Int J Gynecol Pathol. 2008;27:58-60.

11. Caglar H, Traub B, Jenis EH, Gaeta J, Nezhat C, Hreshchyshyn MM. Plexiform or sex cord tumors resembling tumors of the uterus. Am J Obstet Gynecol. 1983;145:639-40.
12. Calisir C, Inan U, Yavas US, Isiksoy S, Kaya T. Mazabraud's syndrome coexisting with a uterine tumor resembling an ovarian sex cord tumor (UTROSCT): A case report. Korean J Radiol. 2007;8:438-42.

13. Cetinkaya N, Bas S, Cuylan ZF, Erdem O, Erkaya S, Gungor T. Uterine tumors resembling ovarian sex cord tumors: A case report and literature review. Oncol Lett. 2016;11:1496-8.

14. de Leval L, Lim GS, Waltregny D, Oliva E. Diverse phenotypic profile of uterine tumors resembling ovarian sex cord tumors: An immunohistochemical study of 12 cases. Am J Surg Pathol. 2010;34:1749-61.

15. Eltabbakh GH, Samter GT. Sex cord tumors of the uterus. Int J Gynaecol Obstet. 1995;48:113-4.

16. Endo D, Todo Y, Okamoto K, Suzuki H. A case of recurrent group II uterine tumor resembling ovarian sex-cord tumors, against which two hormonal agents were ineffective. Taiwan J Obstet Gynecol. 2016;55:751-3.

17. Fekete PS, Vellios F, Patterson BD. Uterine tumor resembling an ovarian sex-cord tumor: Report of a case of an endometrial stromal tumor with foam cells and ultrastructural evidence of epithelial differentiation. Int J Gynecol Pathol. 1985;4:378-87.

18. Garuti G, Gonfiantini C, Mirra M, Galli C, Luerti M. Uterine tumor resembling ovarian sex cord tumors treated by resectoscopic surgery. J Minim Invasive Gynecol. 2009;16:23640.

19. Giordano G, Lombardi M, Brigati F, Mancini C, Silini EM. Clinicopathologic features of 2 new cases of uterine tumors resembling ovarian sex cord tumors. Int J Gynecol Pathol. 2010;29:459-67.

20. Gomes JR, Carvalho FM, Abrao M, Maluf FC. Uterine tumors resembling ovarian sex-cord tumor: A case-report and a review of literature. Gynecol Oncol Rep. 2016;15:22-4.

21. Gutierrez-Pecharroman A, Tirado-Zambrana P, Pascual A, Rubio-Marin D, Garcia-Cosio M, Moratalla-Bartolome E, Palacios J. A uterine tumor resembling ovarian sex cord tumor associated with tamoxifen treatment: A case report and literature review. Int J Gynecol Pathol. 2014;33:151-5.

22. Hashmi AA, Faridi N, Edhi MM, Khan M. Uterine tumor resembling ovarian sex cord tumor (UTROSCT), case report with literature review. Int Arch Med. 2014;7:47.

23. Hauptmann S, Nadjari B, Kraus J, Turnwald W, Dietel M. Uterine tumor resembling ovarian sex-cord tumor-a case report and review of the literature. Virchows Arch. 2001;439:97-101.

24. Hillard JB, Malpica A, Ramirez PT. Conservative management of a uterine tumor resembling an ovarian sex cord-stromal tumor. Gynecol Oncol. 2004;92:347-52.

25. Irving JA, Carinelli S, Prat J. Uterine tumors resembling ovarian sex cord tumors are polyphenotypic neoplasms with true sex cord differentiation. Mod Pathol. 2006;19:17-24.

26. Jeong KH, Lee HN, Kim MK, Kim ML, Seong SJ, Shin E. Successful delivery after conservative resectoscopic surgery in a patient with a uterine tumor resembling ovarian sex cord tumor with myometrial invasion. Obstet Gynecol Sci. 2015;58:418-22. 
27. Kabbani W, Deavers MT, Malpica A, Burke TW, Liu J, Ordonez NG, Jhingran A, Silva EG. Uterine tumor resembling ovarian sexcord tumor: Report of a case mimicking cervical adenocarcinoma. Int J Gynecol Pathol. 2003;22:297-302.

28. Kantelip B, Cloup N, Dechelotte P. Uterine tumor resembling ovarian sex cord tumors: Report of a case with ultrastructural study. Hum Pathol. 1986;17:91-4.

29. Krishnamurthy S, Jungbluth AA, Busam KJ, Rosai J. Uterine tumors resembling ovarian sex-cord tumors have an immunophenotype consistent with true sex-cord differentiation. Am J Surg Pathol. 1998;22:1078-82.

30. Liu CY, Shen Y, Zhao JG, Qu PP. Clinical experience of uterine tumors resembling ovarian sex cord tumors: A clinicopathological analysis of 6 cases. Int J Clin Exp Pathol. 2015;8:4158-64.

31. Macak J, Dundr P, Dvorackova J, Klat J. Uterine tumors resembling ovarian sex cord tumors (UTROSCT). Report of a case with lymph node metastasis. Cesk Patol. 2014;50:46-9.

32. Motiwala N, Shih H, Chen L, Lin JH. A 63-year-old woman with chronic pelvic pain. Uterine tumor resembling ovarian sex cord tumor. Arch Pathol Lab Med. 2006;130:e74-6.

33. Nogales FF, Stolnicu S, Harilal KR, Mooney E, Garcia-Galvis OF. Retiform uterine tumours resembling ovarian sex cord tumours. A comparative immunohistochemical study with retiform structures of the female genital tract. Histopathology. 2009;54:471-7.

34. O’Meara AC, Giger OT, Kurrer M, Schaer G. Case report: Recurrence of a uterine tumor resembling ovarian sex-cord tumor. Gynecol Oncol. 2009;114:140-2.

35. Sitic S, Korac P, Peharec P, Zovko G, Perisa MM, Gasparov S. Bcl-2 and MALT1 Genes are not involved in the oncogenesis of uterine tumors resembling ovarian sex cord tumors. Pathol Oncol Res. 2007;13:153-6.

36. Umeda S, Tateno M, Miyagi E, Sakurai K, Tanaka R, Tateishi Y, Tokinaga A, Ohashi K, Furuya M. Uterine tumors resembling ovarian sex cord tumors (UTROSCT) with metastasis: Clinicopathological study of two cases. Int J Clin Exp Pathol. 2014;7:1051-9.
37. Usadi RS, Bentley RC. Endometrioid carcinoma of the endometrium with sertoliform differentiation. Int J Gynecol Pathol. 1995;14:360-4.

38. Watrowski R, Jager C, Mockel J, Kurz P, Schmidt D, Freudenberg $\mathrm{N}$. Hysteroscopic treatment of uterine tumor resembling ovarian sex cord-like tumor (UTROSCT). Gynecol Endocrinol. 2015;31:856-9.

39. Gargiulo MN, Capellino P, Bacigaluppi AD, Cassanello G, Guagnini MCF, Danieli FP, Crivelli R. Tumor endometrial sìmil tumor de cordones sexuales asociado al uso de tamoxifeno. Revista del HPC. 2008;11:22.

40. Wang J, Blakey GL, Zhang L, Bane B, Torbenson M, Li S. Uterine tumor resembling ovarian sex cord tumor: Report of a case with $\mathrm{t}(\mathrm{X} ; 6)(\mathrm{p} 22.3 ; \mathrm{q} 23.1)$ and $\mathrm{t}(4 ; 18)(\mathrm{q} 21.1 ; \mathrm{q} 21.3)$. Diagn Mol Pathol. 2003;12:174-80.

41. Sadeh R, Segev Y, Schmidt M, Schendler J, Baruch T, Lavie O. Uterine tumors resembling ovarian sex cord tumors: Case report of rare pathological and clinical entity. Case Rep Obstet Gynecol. 2017;2017:2736710.

42. Ucar MG, Ilhan TT, Gul A, Ugurluoglu C, Celik C. Uterine tumour resembling ovarian sex cord tumour- a rare entity. J Clin Diagn Res. 2016;10:QD05-QD7.

43. Moore M, McCluggage WG. Uterine tumour resembling ovarian sex cord tumour: First report of a large series with follow-up. Histopathology. 2017;71:751-9.

44. Pradhan D, Mohanty SK. Uterine tumors resembling ovarian sex cord tumors. Arch Pathol Lab Med. 2013;137:1832-6.

45. Baker RJ, Hildebrandt RH, Rouse RV, Hendrickson MR, Longacre TA. Inhibin and CD99 (MIC2) expression in uterine stromal neoplasms with sex-cord-like elements. Hum Pathol. 1999;30:671-9. 